\title{
SETTLEMENT NETWORK CONCENTRATION AS DETERMINANT FOR RURAL AREAS DEVELOPMENT
}

\author{
Barbara Prus ${ }^{1}$, Stanislaw Bacior ${ }^{1}$, Małgorzata Dudzinska ${ }^{2}$ \\ ${ }^{1}$ Agricultural University in Kraków, Poland; ${ }^{2}$ University of Warmia and Mazury in Olsztyn, Poland \\ b.prus@ur.krakow.pl,geomm@poczta.onet.pl,gosiadudzi@uwm.edu.pl
}

\begin{abstract}
Space planning and development play an ancillary role in relation to settlement and its geography. Residential areas were evolving over the centuries changing their shape as well as architectural forms. Observing the tendencies of the last decades, there is more scattered housing that occurs in landscapes of Polish country, which is also reflected in national spatial politics, in established planning documents, however, it does not always result from real demographic needs. Already existing buildings are less and less adapted for habitation. Together with progressive housing scattering, rural areas' functions change as well. So the question arises is multifunctional development of rural areas the reason of decline of their agricultural function? As well as is building concentration connected with the level of development of particular settlement units? The paper is aimed at comparing the housing concentration coefficients of the chosen settlement units and then confronting them with the calculated synthetic metha-indicators that determine the socio-economic development level. The analysis of building concentration of settlement units was performed by means of the concentration coefficient on the plane. To determine the level of socio-economic development (metha-feature), the spatial taxonomy method was used on the basis of selected diagnostic features. Cross-compliance of a qualitative nature of socioeconomic development compared to building concentration indexes was determined by means of the Pearson correlation coefficient on the basis of the Guilford's classification. Analyzing the geographic phenomenon of building concentration, mathematical and statistical methods and also a monographic method of the subject literature analysis were used. The methods of spatial taxonomy as well as the method of ranking by a synthetic feature were used to survey the socio-economic development phenomenon. The researches were performed in selected rural communes from the area of Małopolska province in Southern Poland.
\end{abstract}

Keywords: residential areas, settlement geography, socio-economic development, spatial taxonomy.

\section{Introduction}

Both, the structure, functioning of rural areas and land use are considerably different across Europe. This situation is the result of cultural differences and also different land use requirements or population densities [1]. Some of premises of various stages of countries' development point to the fact that spatial planning legislation has been reacting ptoo slowly to manage potential social and economic problems [2]. It is well known that social and economic efficiency of development of the country determines the sustainable development of its rural areas [1]. Rural areas become the most important economic and demographic component of the country [3]. The strategic role in ensuring stability of the state and strengthening food security [4-5] decided that rural areas development is at present one of the most important problems in the world [6-8].

Agricultural areas of South Poland are described as small, family-owned agricultural holdings [9]. They are characterized by an extensive land use mosaic [10]. The current stage of socio-economic development of rural areas in Poland results most of all from political changes in 1989 [11] and is conditioned by Poland's accession to the EU structures in 2004. Since that moment, local agriculture has received considerable financial assistance that enabled significant changes in the land use structure [9] including land consolidation [12]. The shape of rural areas is directly conditioned by the settlement network structure. Building density within concentration or population centres phenomenon together with their capital, buildings and infrastructure is in many countries of the world a determinant of the cities' definition [13]. Although the concept of urbanization includes the idea of concentration, defining the size and character of an agglomeration is a bit arbitrary in the context of two aspects. The first is a limit number of people in a group and the second one - the nature of grouped buildings where they live as well as connections between them. Settlement units are created by set aside groups of buildings together with buildings and devices connected with them. Their borders are determined narrowly or widely, which results from incompatibility of definitions of statistical and physical spaces. However, built-up area contains lands, which are not always really covered with buildings [14]. In the last half-century, dynamic increase of areas occupied by settlement areas and communication lands took place [15]. After the World War I, the rural area of southern Poland was characterized by high density of housing, i.e. on average 14 buildings per $1 \mathrm{~km}^{2}$. The mean was higher than the one for the 
whole Poland, which was 9 buildings per $1 \mathrm{~km}^{2}$ [16]. Increase of built-up areas in rural regions occurred not only as a result of densification of housing and along communication routes, but also by location of dispersed settlement on the slopes and alluvial terraces [17-18].

Spatial planning determines development of settlement units according to the rule of sustainability, which is using space and environment as limited goods [19]. Spatial politics influences future directions of spatial development by planning elaborations, which permit or limit possible building on the areas that are used for agricultural purposes [20-21]. So, this is the spatial planning system, which should provide proper usage of the social and economic potential and thereby proper development of rural areas. The space limited character causes that lands are subject to strong pressure and competition [22-23] and for that reason postulates for economical management of these areas are proceeded [24-26]. Particularly negative results of urban pressure occur in case of rural production space including lands with high productive values in particular [27-28]. Evaluation of the sustainability level should be based on social, economic and environmental indications [29]. Socioeconomic conditions depend on internal (endogenous) and external (exogenous) indicators. Next to the external conditions of communes functioning, the endogenous indicators are the basis for development of local economy [30-31]. The problem of socio-economic development is connected with the analysis of increase of the investments' number, values of production, employment as well as inhabitants' living standards and social and public security in a long-range period [32]. Among local determinants of development, these resulting directly from the needs of inhabitants and also connected with local resources can be found. Indicators of socio-economic development can be grouped in such categories: economic and social ones and also these, which are dependent on the infrastructure [33]. On the contrary, the phenomenon of socio-economic development itself can be described by a big number of variables [34]. However, to evaluate the socio-economic phenomena, coefficients, which allow to draw conclusions about ongoing processes, are required [35]. This is not an easy task to be realized because selection of coefficients in quantitative analyses depends on data availability and subjective assessments, but it should have substantive justification.

\section{Materials and methods}

The paper is aimed at comparing the housing concentration coefficients of the chosen settlement units and then confronting them with the calculated synthetic metha-indicators that determine the socio-economic development level. The analysis of building concentration of settlement units was performed by means of the concentration coefficient on the plane. To determine the level of socio-economic development (metha-indicator), the spatial taxonomy method was used on the basis of chosen diagnostic features.

Determining of the level of socio-economic development was performed in four stages. The first one consisted of defining the indicators that quantify the development of rural areas. Based on the definitions of socio-economic development, usage of three groups of indicators: social, economic and also technical and social infrastructure ones is proposed as in Table 1. A diagnostic feature with assumption that it should be specific for the surveyed phenomenon, it should have high variation and at the same time it should be strongly correlated with non-diagnostic features from its informative group and weakly correlated with the other features concerned diagnostics was selected in every group [36]. Being guided by these indications, such variables were selected as diagnostics features: $\mathrm{x}_{2}$ - number of people in non-productive age per 100 of people in working age, i.e. so called coefficient of demographic dependency ratio, $\mathrm{x}_{6}$ - expenditures of commune's budget per 1 citizen, $\mathrm{x}_{7}$ - apartments provided for using. Further analyses were performed on the selected diagnostics features.

On the second stage, rating of the selected indicators that involved bringing dissimilar indicators measured in different units to dimensionless values ranging from 0 to 1 was conducted. They were calculated as the ratio of the difference between the indicator's value and its minimum value and the difference between the maximum and minimum values of the indicator. The indicators were calculated according to the formula:

$$
X_{i j}^{\prime}=\left(\frac{X_{i j}-X_{j \min }}{X_{j \max }-X_{j \min }}\right),
$$

where $X_{i j}^{\prime}$ - variable standardized value; 
$x_{i j}-i$ value of $j$ indicator;

$x_{j \max }, x_{j \min }-$ maximum and minimum values of $j$ indicator.

Table 1

Indicators for the assessment of socio-economic development in rural areas

\begin{tabular}{|c|c|c|c|c|}
\hline $\begin{array}{c}\text { Indicator } \\
\text { number }\end{array}$ & Indicator title & $\begin{array}{l}\text { Mean } \\
\text { value for } \\
\text { indicators }\end{array}$ & $\begin{array}{l}\text { Standard } \\
\text { deviation }\end{array}$ & $\begin{array}{l}\text { Coefficient } \\
\text { of variation, } \\
\%\end{array}$ \\
\hline \multicolumn{5}{|c|}{$\begin{array}{c}\text { Social } \\
\end{array}$} \\
\hline$x_{1}$ & Number of people per $1 \mathrm{~km}^{2}$ (density of population) & 68.64 & 34.93 & 58.9 \\
\hline$x_{2}$ & $\begin{array}{c}\text { Number of people in non-productive age per } 100 \\
\text { people in working age }\end{array}$ & 65.04 & 3.10 & 4.8 \\
\hline$x_{3}$ & Number of working people per 1000 people & 80.99 & 52.12 & 64.4 \\
\hline $\boldsymbol{x}_{4}$ & $\begin{array}{c}\text { Percentage of registered unemployed people in the } \\
\text { number of people in working age, } \%\end{array}$ & 6.05 & 1.16 & 19.1 \\
\hline \multicolumn{5}{|c|}{ Economic } \\
\hline$x_{5}$ & $\begin{array}{l}\text { Total incomes of commune's budget per } 1 \text { inhabitant } \\
\text { in PLN }\end{array}$ & $3,142.70$ & 487.56 & 15.5 \\
\hline$x_{6}$ & $\begin{array}{c}\text { Total expenditures of commune's budget } \\
\text { per } 1 \text { inhabitant in PLN }\end{array}$ & $3,050.18$ & 500.71 & 16.4 \\
\hline \multicolumn{5}{|c|}{ Social and Technical Infrastructure } \\
\hline $\boldsymbol{x}_{7}$ & Apartments provided for using per 1000 inhabitants & 12.29 & 16.38 & 133.3 \\
\hline$x_{8}$ & Entities in REGON register & 627.14 & 820.22 & 130.8 \\
\hline$x_{9}$ & Rate of people that use water supply & 84.09 & 7.94 & 9.4 \\
\hline $\boldsymbol{x}_{10}$ & Rate of people that use waste water installation & 16.34 & 18.79 & 115.0 \\
\hline$x_{11}$ & Rate of people that use gas installation & 5.00 & 7.28 & 145.7 \\
\hline$x_{12}$ & $\begin{array}{c}\text { Number of entities in the category A_01 of the Polish } \\
\text { Classification of Activities from } 2007 \text { (arable crops, } \\
\text { animal breeding, hunting) }\end{array}$ & 17.86 & 8.91 & 49.9 \\
\hline
\end{tabular}

Source: own study

The third stage consists of calculation of the initial set of indicators of each component of rural areas socio-economic development. The fourth stage includes calculation of a complex integrated indicator of socio-economic development to each community.

The synthetic coefficient of development was divided into four class sections [37]. Creating the class sections, arithmetic mean $\left(R_{a m}\right)$ of obtained estimations of synthetic sizes and the coefficient of development level for every commune as well as a standard deviation were used assuming that the communes are distinguished by the following levels of development:

1. A. high, for which the condition $\left(R_{i}>R_{a m}+s\right)$ was fulfilled,

2. B. fairly high $\left(R_{a m}+s>R_{i}>R_{a m}\right)$,

3. C. average $\left.R_{a m}>R_{i}>R_{a m}-s\right)$,

4. D. low $\left(R_{a m}-s>R_{i}\right)$,

where $R_{i}$ - synthetic coefficient of development in a settlement;

$R_{a m}$ - arithmetic mean of the synthetic coefficient of development;

$s$ - standard deviation of the synthetic coefficient.

Following the aim of the paper, the degree of housing in individual units (communes) was determined by means of the coefficient of concentration on the plane. Mutual location of buildings as points on the plane was taken into consideration. On the basis of assumptions of the graph theory, it is possible to study a system that illustrates points on the plane (buildings) together with their mutual locations. Such system keeps complete information about the configuration of points [38]. Passing from the graph theory to the language of analytic geometry, to calculate the concentration of a cloud of points on the plane (in two-dimensional space) the following formula was used (provided that calculations concern a big number of objects):

$$
C 2=\frac{1}{S x^{2}+S y^{2}},
$$


where $C_{2}$ - coefficient of concentration on the plane;

$S x^{2}$ - variance of $x$ coordinate in examined set of points;

$S y^{2}-$ variance of $y$ coordinate in examined set of points.

The surveys were carried out in the area of communes of Miechów district (Małopolska province) (Fig. 1).

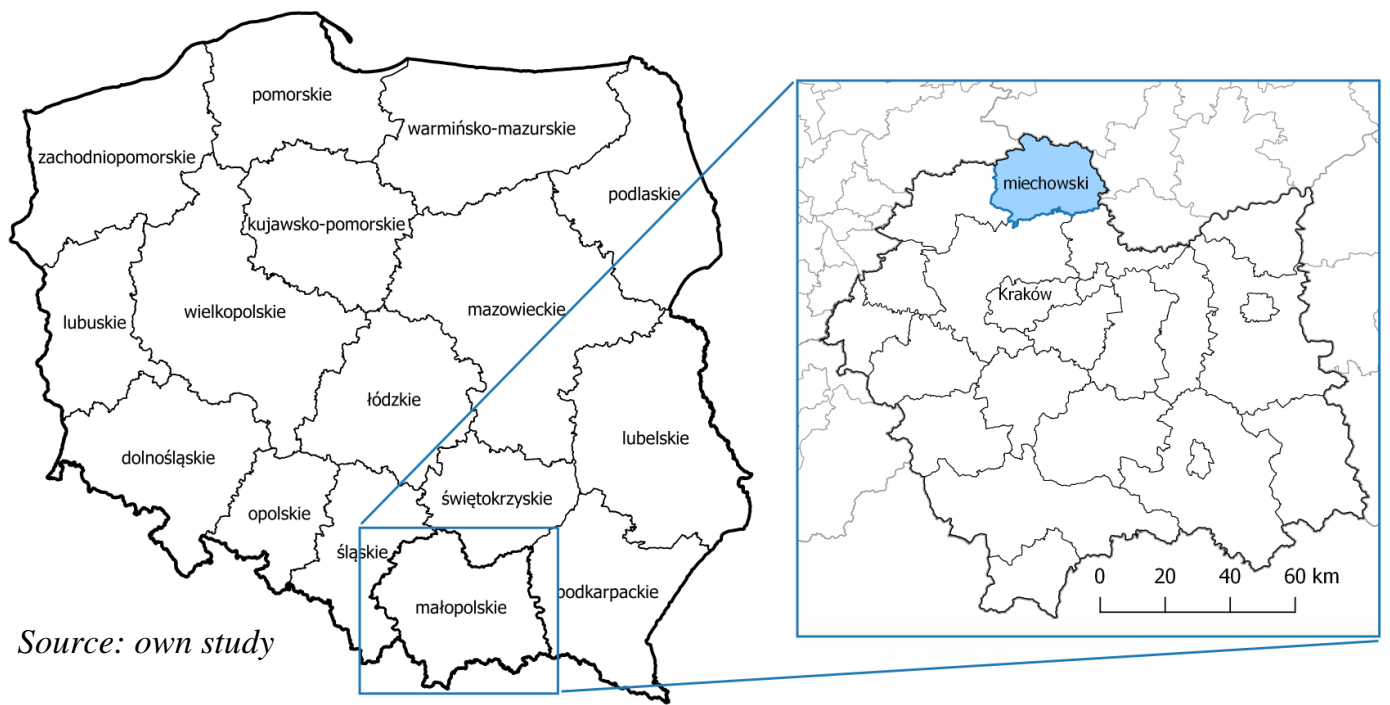

Fig. 1. Location of the case study - Miechów district in Małopolska province, South Poland

Miechów district is situated in the northern part of Małopolska province near the border with Świętokrzyskie province (Fig. 1). It contains seven communes. They are: Charsznica, Gołcza, Kozłów, Książ Wielki, Miechów, Racławice and Słaboszów. The area of the district is 67.5 thousand ha. The area of the district is included by Miechów Upland, the region limited from the south by the valley of Vistula river and from the north with valleys of Pilica and Nidzica rivers. It is built of Jurassic limestone and Cretaceous marls covered by loess coatings. The landscape of carbonate wavy plateaus dominates here and the one of less highlands - in the southern part. Predominantly, the area is typically agricultural.

\section{Results and discussion}

The carried out calculations show that the level of the synthetic metha-indicator in three communes is on the relatively high level and in the two others - on the average level. One of the communes (Table 2) of Miechów district is characterized by a low level of socio-economic development and one - by a high level. The mean value of the calculated coefficient is 0.34 , whereas the standard deviation is 0.12 .

The communes of Miechów district can be divided into two groups (Fig. 2.): eastern - less developed, to which Charsznica, Gołcza and Kozłów communes can be included, and south-western, i.e. Słaboszów, Racławice, Książ Wielki and Miechów communes.

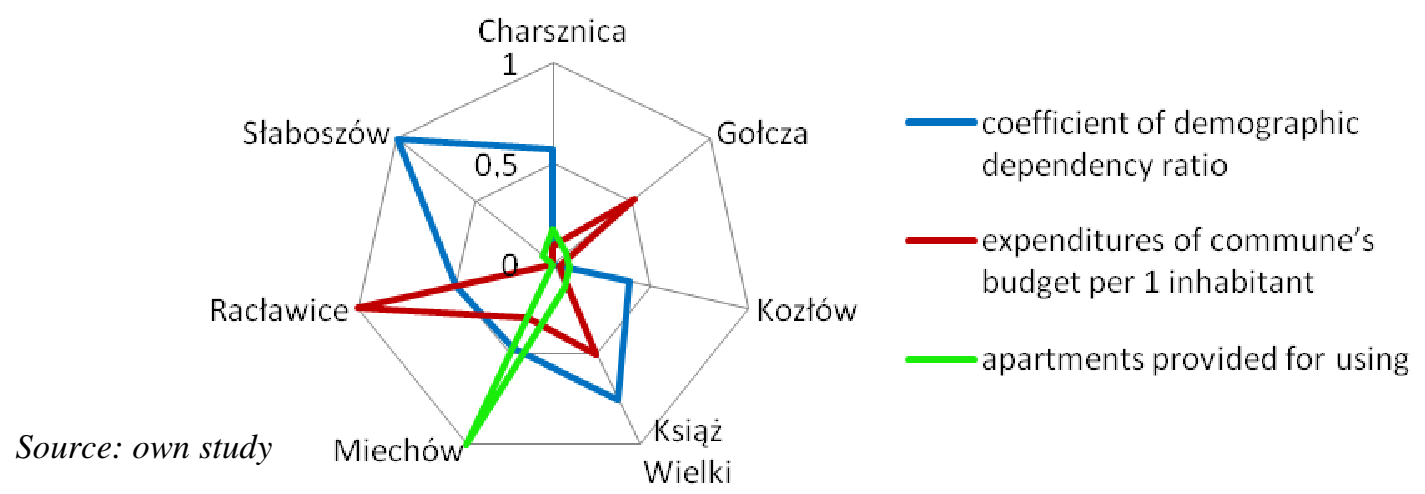

Fig. 2. Participation of individual groups of factors in socio-economic development 
Learning the stages of socio-economic development of administrative units matters in making strategic decisions by local authorities that concern supporting less developed regions [39; 40]. Welldeveloped communes are characterized by a high coefficient of a number of people in non-productive age in relation to people in working age, high value of commune's budget expenditures per 1 inhabitant and also high percent of apartments provided for using (Fig. 2).

Table 2

\section{Summary of metha-synthetic indicators that characterize socio-economic conditions of communes}

\begin{tabular}{|c|c|c|c|c|c|}
\hline Commune & $\begin{array}{c}\text { Metha- } \\
\text { synthetic } \\
\text { indicator }\end{array}$ & $\begin{array}{c}\text { Level of socio- } \\
\text { economic } \\
\text { conditions }\end{array}$ & $\begin{array}{c}\text { Housing density } \\
\text { (number of } \\
\text { buildings per } \mathbf{~ k m}^{\mathbf{2}} \text { ) }\end{array}$ & $\begin{array}{c}\text { Concentration } \\
\text { coefficient }\end{array}$ & $\begin{array}{c}\text { Relative value of } \\
\text { concentration } \\
\text { coefficient, } \mathbf{~ k m}^{-2}\end{array}$ \\
\hline Charsznica & 0.46 & Relatively high & 98.3 & 0.08998 & 0.00115 \\
\hline Gołcza & 0.32 & Average & 63.4 & 0.05157 & 0.00057 \\
\hline Kozłów & 0.13 & Low & 56.5 & 0.07316 & 0.00085 \\
\hline Książ Wielki & 0.36 & Relatively high & 40.3 & 0.04848 & 0.00035 \\
\hline Miechów & 0.49 & High & 80.4 & 0.04710 & 0.00032 \\
\hline Racławice & 0.38 & Relatively high & 92.6 & 0.11814 & 0.00200 \\
\hline Słaboszów & 0.27 & Average & 105.1 & 0.06408 & 0.00084 \\
\hline
\end{tabular}

Source: own study

From among the tested communes, the greatest number of buildings per $1 \mathrm{~km}^{2}$ occurs in Słaboszów and Charsznica communes followed by Racławice and Miechów ones. The smallest amount of buildings per $\mathrm{km}^{2}$ is in Książ Wielki commune. Correlative relation between the housing density and housing concentration coefficient is 0.508 . Correlation between the synthetic methaindicator and housing concentration is 0.017 , so its lack can be stated. Taking the Guilford's classification into consideration, only average positive correlation at the level of 0.314 between the communes' development level and the number of buildings per $\mathrm{km}^{2}$ can be noticed.

\section{Conclusions}

Learning the stages of socio-economic development of administrative units matters in making strategic decisions by local authorities that concern supporting less developed regions. The level of development is a phenomenon, which differentiates communes between each other. Various factors influence the level of development. The level of socio-economic development of the examined communes is differentiated by the area of the district to the eastern and south-western parts. The most highly evaluated socio-economic conditions occur in Miechów commune and the lowest - in Kozłów one. The most numerous group of communes, i.e. $43 \%$, are these with the relatively high level of development (Charsznica, Książ Wielki and Racławice communes). In $28 \%$ of the communes, the level of development is at the average level. The coefficient of housing concentration depends on mutual location of buildings in space. It is different for various communes. The analyses of the housing concentration rate in individual units (communes) revealed that the highest level concerns Racławice commune (0.11814), whereas the lowest one is in Miechów and Książ Wielki communes ( 0.04710 and 0.04848 , respectively) with the mean level 0.07036 . The relative value of the housing coefficient per $\mathrm{km}^{2}$ is the highest in Racławice commune and amounts 0.002 , whereas the lowest one is in Miechów commune -0.0032 with the mean value 0.000867 . The determined levels are approximate for the housing concentration coefficient as well as the relative housing concentration coefficient. Relation between the specified level of socio-economic development and the concentration coefficients was not found. It means that spatial arrangement of housing or the grade of buildings' concentration we are dealing with does not affect the level of socio-economic development reached by settlement units. One of reasons of such situation can be the fact that the housing concentration coefficients did not differentiate built-up areas in relation to the accepted function of development, which can possibly influence the socio-economic level of development. Performing other analyses in this direction could lead to revealing the aforementioned relations. However, it is the density of housing that affects the development. Greater number of buildings per $\mathrm{km}^{2}$ means higher grade of socio-economic development of a settlement unit. 


\section{References}

1. Bilan Y., Chmielewska B. Diversified economic and social situation of farms of the European Union as a determinant of the rural areas growth policy. Actual Problems of Economics. 2013; 2(10), pp. 213-221.

2. Hernik J., Gawroński K., Dixon-Gough R. Social and economic conflicts between cultural landscapes and rural communities in the English and Polish systems. Land Use Policy 30, 2013, pp. 800-813.

3. Semenova N. N., Busalova S. G., Eremina O. I., Makeikina S. M., Ivanova I. A. Assessment of Sustainable Development of Rural Areas of Russia. Indian Journal of Science and Technology, 9 (14), 2016, pp. 1-7.

4. Kormishkina L. A., Semenova N. N., Krutova I. N., Sausheva O. S. Food security in the system of relations of the standard and quality of life. World Applied Sciences Journal 25, 2013, pp. 15361541.

5. Ayres W. S., McCalla A. F. Rural development, agriculture and food security. Financ. Dev. 33, 1996, pp. 8-11.

6. Petrick M., Buchenrieder G. Sustainable rural development: What is the role of the agri-food sector? Studies on the Agricultural and Food Sector in Central and Eastern Europe, 39, 2007, pp. $18-27$.

7. Torre A., Wallet E. Innovation and governance of rural territories [In:] E. Cloudel, H. Devautour H., C. T. Soulard, G. Faure, B. Hubert (Eds.) Renewing Innovation Systems in Agriculture and Food: How to get towards more sustainability? Wageningen Academic Publishers, 2013.

8. Lanfranchi M., Giannetto C. Sustainable development in rural areas: The new model of social farming. Quality - Access to Success, 15, 2014, pp. 219-223.

9. Baran-Zgłobicka B., Zgłobicki W. Mosaic landscapes of SE Poland: should we preserve them? Agroforest Syst. 85, 2012, pp. 351-365.

10. Skowronek E., Krukowska R., Świeca A., Tucki A. The evolution of rural landscapes in mideastern Poland as exemplified by selected villages. Landscape and Urban Planning 70, 2005, pp. 45-56.

11. Łowicki D. Land use changes in Poland during transformation: case study of Wielkopolska Region. Landscape and Urban Planning 87, 2008, pp. 278-288.

12. Dudzińska, M., Kocur-Bera, K. (2015). Community education and integrated organization of rural areas based on land consolidation processes in Poland. Proceedings of the International Scientific Conference Rural Environment. Education. Personality, 34-41.

13. Szymańska D. Geografia osadnictwa. Wydawnictwo Naukowe PWN. Warszawa, 2009. 398 p.

14. Dziewoński K. The integration of statistical and cartographical analysis for research purposes. Regional Science Association Papers vol. 15, 1965, pp. 119-129.

15. Angiel M., Gmiąt A., Patoczka P., Pietrzak M. The initiative for the saving of the cultural heritage of Carpathian Foothills in the vicinity of Brzesko. Polish Journal of Environmental Studies, vol. 15, No 5C, pp. 79-82.

16. Angiel M., Pietrzak M. Wieś tradycyjna w krajobrazie Pogórzy Karpackich. Polskie Krajobrazy Wiejskie Dawne i Współczesne. Prace Komisji Krajobrazu Kulturowego Nr 12. Komisja Krajobrazu Kulturowego PTG, Sosnowiec 2009, pp. 13-32.

17. Kowicki M. Wybrane zagadnienia planistyczno-przestrzennego kształtowania wsi beskidzkiej ze szczególnym uwzględnieniem problemów architektoniczno-krajobrazowych. Prace Komisji Krajobrazu Kulturowego PTG, vol. III, Sosnowiec 2004, pp. 144-154.

18. Pietrzak M. Relationship between settlement and relief in the Polish Carpathian Mountains, [In:] W. Zgłobicki, J. Rejman (eds.) Human impact on sensitive geosystems. Maria Curie-Skłodowska University Press, Lublin 2005, pp. 65-82.

19. Domański R. Gospodarka przestrzenna. Podstawy teoretyczne. Wydawnictwo Naukowe PWN, Warszawa 2013.

20. Ustawa o planowaniu i zagospodarowaniu przestrzennym z dnia 27 marca 2003 r. (Act of 27 March 2003 on Spatial Planning and Management). Dz.U. nr 80, poz. 717 z późn. Zm. (Journal of Laws, No. 80, item 717 as amended).

21. Hełdak M.: Plan miejscowy jako narzędzie ograniczania niekontrolowanego rozwoju zabudowy strefy podmiejskiej [In:] St. Korenik, Z. Przybyła (red.) Gospodarka Przestrzenna XI, Wyd. Uniwersytetu Ekonomicznego we Wrocławiu, Wrocław 2008. 
22. Mrozik K., Bossy M., Zaręba K.: Polityka przestrzenna gmin wiejskich na tle zmian zagospodarowania przestrzennego wynikających z suburbanizacji (Spatial Policies in Rural Comunes in the Context of Economic Changes Brought on by Suburbanization), Rocznik Ochrony Środowiska Vol. 14, pp. 761-771.

23. Mrozik K., Wiśniewska A.: Miejscowe plany zagospodarowania przestrzennego jako instrument zarządzania procesem suburbanizacji na terenach wiejskich na przykładzie obrębu geodezyjnego Skórzewo (Local Spatial Management Plans as an Instrument for Managing Suburbanization Processes in Rural Areas Exemplified by the Cadastral Unit of Skórzewo), Rocznik Ochrony Środowiska, Vol. 15, pp. 2126-2141.

24. Szulczewska B.: Koncepcja rozwoju zrównoważonego jako podstawa strategii regionalnej uwagi metodyczne. [w]: B. Szulczewska (red.), Przyrodnicze aspekty zrównoważonego rozwoju. Człowiek i Środowisko 24/2, IGPiK, Warszawa 2000, pp. 137-153.

25. Matysiak J.: Człowiek a ład przestrzeni. W: T.J. Chmielewski (red.), Nowa jakość krajobrazu. Ekologia-Kultura-Technika, Komitet PAN Człowiek i Środowisko, Zeszyty Naukowe 36. Warszawa-Lublin 2004, pp. 59-69.

26. Poniży L.: Presja urbanizacyjna i jej wpływ na zmiany przestrzennej struktury użytkowania ziemi na wybranych obszarach podmiejskich Poznania. Problemy Ekologii Krajobrazu, 2008, T. XXII. pp. 335-342.

27. Koreleski K.: Aktualne zasady kształtowania rolniczej przestrzeni produkcyjnej w Anglii i Walii. Przegląd Geodezyjny 6/1994.

28. Prus B., Salata T.: Analiza zasobów rolniczej przestrzeni produkcyjnej w polityce przestrzennej gminy Tomice. Infrastruktura i Ekologia Terenów Wiejskich. PAN. Komisja Technicznej Infrastruktury Wsi. Kraków, 3/II/2013 pp. 145-157.

29. Kates R. W., Parris T. M., Leiserowitz A. A.: What is sustainable development? Goals, Indicators, Values and Practice. Environment: Science and Policy of Sustainable Development, 2005, No 47 (3). pp. 8-23.

30. Hryniewicz J. Endo- i egzogeniczne czynniki rozwoju gospodarczego gmin i regionów. EIRRiL, Studia Regionalne i Lokalne, nr 2, 2000.

31. Swianiewicz P., Łukomska J. Władze samorządowe wobec lokalnego rozwoju gospodarczego. Które polityki są skuteczne? Samorząd Terytorialny. Nr 6, 2004.

32. Kuciński K. (red.), Geografia ekonomiczna, Oficyna Wolters Kluwer Polska, 2009.

33. Parysek J. Rola samorządu terytorialnego w rozwoju lokalnym. [w:] Rozwój lokalny zagospodarowanie przestrzenne i nisze atrakcyjności gospodarczej. PAN, PWN Warszawa 1995.

34. Grabiński T., Wydymus S., Zeliaś A. Metody prognozowania rozwoju społeczno gospodarczego, PWE, Warszawa 1983.

35. Nowak E., Metody taksonomiczne w klasyfikacji obiektów społeczno-gospodarczych [Taxonomic methods in the classification of socio-economic objects], Wyd. PWE, Warszawa 1990.

36. Kolenda M., Taksonomia numeryczna: klasyfikacja, porządkowanie i analiza obiektów wielocechowych, [Numerical taxonomy. Classification, organization and analysis of multivariate objects], Wyd. Akademii Ekonomicznej we Wrocławiu 2006, pp. 359.

37. Ziemiańczyk U. Ocena poziomu rozwoju społeczno-gospodadrczego gmin wiejskich i wiejskomiejskich w woj. małopolskim. Infrastructure and Ecology of Rural Areas, No 14/2010, pp.31-40.

38. Kostrubiec B. Analiza zjawisk koncentracji w sieci osadniczej. Wyd. PAN, Wrocław, Prace geograficzne $\mathrm{Nr}$ 93, $117 \mathrm{p}$.

39. Gorzelany J., Prus B., Salata T., Delimitation of same municipalities of Cracow district in reference to technical and social infrastructure (using numerical taxonomy methods) and impact on local development, In: $15^{\text {th }}$ International Scientific Conference: Engineering for Rural Development/ Malinovska Larisa (red.), Vol. 15, 2016, Latvia University of Agriculture Faculty of Engineering, ss. 387-396.

40. Gawroński K., Prus B., Sołtysik S. Analiza i ocena warunków rozwoju społeczo-gospodarczego województwa podkarpackiego. Infrastruktura i Ekologia Terenów Wiejskich. PAN. Komisja Technicznej Infrastruktury Wsi. Kraków, IV/2/2014 pp. 1241-1254. 